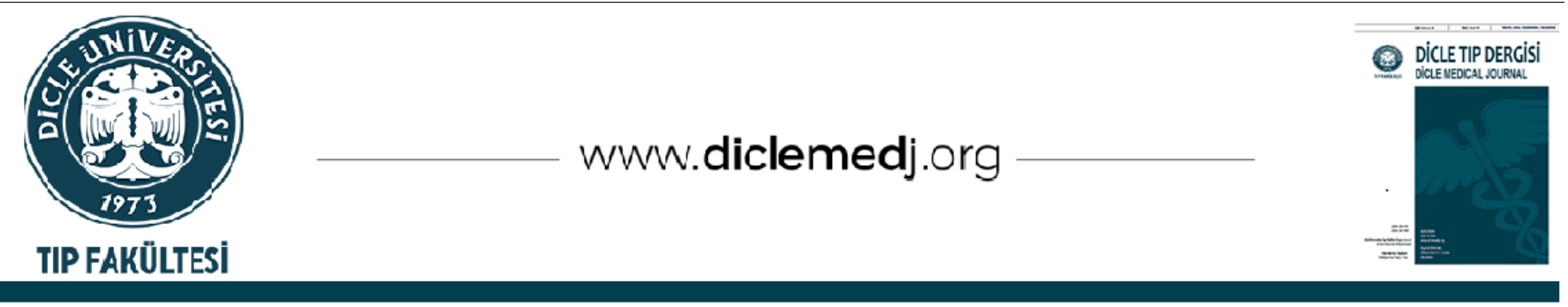

Derleme / Review

\title{
COVID-19: Gebelik, Prenatal Bakım ve Doğum Yönetimi
}

\author{
Senem Yaman Tunç ${ }^{\text {i }}$, Fatih Mehmet Fındık ${ }^{D_{1}}$, Talip Gül ${ }^{i}{ }_{1}$ \\ 1 Dicle Üniversitesi Tıp Fakültesi, Kadın Hastalıkları ve Doğum Anabilim Dalı, Diyarbakır, Türkiye \\ Geliş: 14.09.2021; Kabul Tarihi: 29.09.2021
}

\section{Öz}

COVID-19, 2019'un sonlarında Çin'de ortaya çıkarak tüm dünyaya yayılmıştır. Etken olan virüs "Severe Acute Respiratory Syndrome Coronavirus 2 (SARS-CoV-2)"olarak tanımlanmıştır. Hastalık esas olarak damlacık yoluyla bulaşmaktadır. Genel olarak inkubasyon süresi 2-14 gün arasında değişmektedir. Gebeliğin SARS-CoV-2 enfeksiyonuna duyarlıllğı artırmadığı, ancak aynı yaştaki gebe olmayan kadınlara kıyasla COVID-19'un klinik seyrini kötüleștirdiği bildirilmiştir. Gebelikte ciddi hastalık ve ölüm için risk faktörleri arasında ileri yaş (özellikle $\geq 35$ yaş), obezite ve diğer komorbiditeler ( hipertansiyon, diyabet vb.) yer alır. Vertikal geçişin sıklığı henüz tam olarak bilinmemektedir. Gebelikte geçirilen COVID-19'un düşük, ölü doğum, neonatal ölüm ve konjenital anomali riskini arttırmadığı düşünülmektedir. Erken doğum ve sezaryen doğum oranlarının COVID-19'lu gebelerde arttığı bildirilmiştir. Gebelik sırasında COVID-19 aşılarının güvenliği ve etkinliği ile ilgili giderek daha fazla veriye ulaşılmaktadır. Bu verilere dayanarak gebelerin COVID-19 aşısı olmaları önerilmektedir. Gebelerde komplike olmayan COVID-19 enfeksiyonu için tedavisiz izlem seçeneği öncelikle düşünülmelidir. Olası tanı almış olan gebelerde risk faktörü varsa veya ağır seyir söz konusu ise tedavi verilmesi düşünülmelidir. COVID-19 pozitifliği doğum için bir endikasyon değildir. Doğum şekline rutin endikasyonlara göre karar verilmelidir. Doğumda multidisipliner bir bakım ekibi mevcut olmalıdır. COVID-19 enfeksiyonu olan anneler doğum odasında cerrahi maske takarak ve uygun el hijyeni ile cilt cilde temasta bulunabilir ve emzirme yapabilirler. Tüm yetişkinlerde olduğu gibi doğum sonrası kadınlara da COVID-19 aşısı önerilmektedir.

Anahtar kelimeler: COVID-19, gebelik, tedavi, doğum, aşılar

\section{DOI: $10.5798 /$ dicletip.1004935}

Yazışma Adresi / Correspondence: Senem Yaman Tunç, Dicle Üniversitesi Tıp Fakültesi, Kadın Hastalıkları ve Doğum Anabilim Dall, 21280 Sur/Diyarbakır,Türkiye e-mail: drsenemtunc@hotmail.com 


\title{
COVID-19: Pregnancy, Prenatal Care and Delivery Management
}

\begin{abstract}
COVID-19 originated in China in late 2019 and has spread all over the world. The causative virus has been defined as "Severe Acute Respiratory Syndrome Coronavirus 2 (SARS-CoV-2)". The disease is mainly transmitted by droplets. In general, the incubation period varies between 2-14 days. It has been reported that pregnancy does not increase susceptibility to SARS-CoV-2 infection, but worsens the clinical course of COVID-19 compared to non-pregnant women of the same age. Risk factors for serious illness and death in pregnancy include advanced age (especially $\geq 35$ years), obesity, and other comorbidities (hypertension, diabetes, etc.). The frequency of vertical transition is not yet known exactly. It is thought that COVID-19 during pregnancy does not increase the risk of miscarriage, stillbirth, neonatal death and congenital anomalies. It has been reported that the rates of preterm birth and cesarean delivery are increased in pregnant women with COVID-19. More and more data are available regarding the safety and efficacy of COVID-19 vaccines during pregnancy. Based on these data, it is recommended that pregnant women be vaccinated against COVID19. For uncomplicated COVID-19 infection in pregnant women, the option of follow-up without treatment should be considered first. If there are risk factors or severe prognosis in pregnant women with a possible diagnosis, treatment should be considered. COVID-19 positivity is not an indication for delivery. The mode of delivery should be decided according to routine indications. A multidisciplinary care team should be present at birth. Mothers with COVID-19 infection can make skin-to-skin contact and breastfeed in the delivery room by wearing a surgical mask and with proper hand hygiene. As with all adults, postpartum women are also offered the COVID-19 vaccine.
\end{abstract}

Keywords: COVID-19, pregnancy, treatment, delivery, vaccines.

\section{GíRiş}

Coronavirüs enfeksiyonuna bağlı hastalık, 2019'un sonlarında Çin'de ortaya çıkarak tüm dünyaya yayılmıștır. Dünya Sağlık örgütü (WHO), Şubat 2020'de hastalığı COVID-19 (Coronavirüs hastalığı 2019), etken olan virüsü "Severe Acute Respiratory Syndrome Coronavirus 2 (SARS-CoV-2)"olarak tanımladı ${ }^{1}$. Küresel olarak 200 milyondan fazla COVID-19 vakası rapor edilmiştir. Akut enfeksiyonların yalnızca bir kısmı teşhis edilip rapor edildiğinden, bildirilen vaka sayıları COVID19'un genel yükünü tam olarak yansıtmamaktadır².

Hastalık esas olarak damlacık yoluyla bulaşmaktadır. Ayrıca hasta bireylerin öksürme, hapşırma yoluyla ortaya saçtıkları damlacıklara diğer kişilerin elleri ile temas etmesi sonrasında ellerini ağız, burun veya göz mukozasına götürmesi ve temas etmesi ile bulaşmaktadır. Asemptomatik kişilerin solunum yolu salgılarında da virüs tespit edilebildiğinden bu kişiler bulaştırıcı olabilmektedir.
Genel olarak inkubasyon süresi 2-14 gün arasında değişmektedir. COVID-19'un bulaştırıcılık süresi kesin olarak bilinmemektedir. Semptomatik dönemden 1-2 gün önce bașlayıp semptomların kaybolmasıyla sona erdiği düşünülmektedir. Enfeksiyonun yaygın belirtileri solunum semptomları, ateș, öksürük ve dispnedir. Başağrısı, boğaz ağrısı, burun akıntısı, kas ve eklem ağrıları, aşırı halsizlik, yeni ortaya çıkan koku ve tat alma duyusu kaybı, ishal gibi belirtiler de görülebilmektedir. Hastalık asemptomatik geçirilebilmekle birlikte, ciddi vakalarda, pnömoni, ağır akut solunum yolu enfeksiyonu, böbrek yetmezliği ve hatta ölüm gelişebilmektedir. Şüpheli olgularda tanı, alt (daha duyarlı) ve/veya üst solunum yollarından alınan örneklerin kantitatif reverse transkripsiyon polimeraz zincir reaksiyonu (qRT-PCR) analizi ile konulmaktadır. İlk testi negatif olan ileri derecede kuşkulu vakalarda test tekrarlanır. Eğer iki qRT-PCR analizi de negatif ise COVID-19 dişlanır 3 .

\section{HASTALIĞIN ÖNLENMESİ}


Kişisel koruyucu önlemler - Gebeler, virüse maruziyetten kaçınmak için gebe olmayan kişilerle aynı tavsiyelere uymalıdır. Kalabalık ortamlardan kaçınmak, sosyal mesafeyi korumak (en az 2 metre veya 6 adım), hasta bireylerle yakın temastan kaçınmak ve sokağa çıkarken maske takmak uyulması gereken kişisel önleyici tedbirlerdir ${ }^{4}$.

Evde çocuğu olan gebe anneler dikkatli olmalıdır. 10 yaşın altındaki çocuklarda COVID19 genellikle hafiftir ve ciddi vakalar bildirilmiş olmasına rağmen asemptomatik olabilir ve asemptomatik bireylerden (veya kuluçka dönemi içinde presemptomatik bireylerden) SARS-CoV-2 bulaşması mümkündür. Aşılama bulaşma riskini azaltır.

Uygun kişisel koruyucu ekipman ve el hijyeni kullanan ve uygun çevre temizliği olan bir alanda çalışan gebeler, özellikle de aşılanmış iseler doğum yapana kadar çalışmaya devam edebilirler ${ }^{5}$. Ancak gebenin tıbbi komorbiditeleri ve bireysel çalışma durumu da dikkate alınmalıdır.

Aşılar - COVID-19'un önlenmesi için çok sayıda aşı değerlendirilmiștir. Ancak gebe ve emziren kadınlar bu denemelerin dişında tutulmuștur. Amerika Birleşik Devletleri'nde, iki mRNA aşısı ve bir viral vektör aşısı FDA (Food and Drug Administration) tarafindan acil kullanım izni almıştır. $\mathrm{Bu}$ aşıların hiçbiri çoğalan virüs içermez; bu nedenle hastalığa neden olmazlar, ancak bağıșılklık sisteminin aktivasyonundan spesifik olmayan yan etkiler ortaya çıkabilir. Uzmanlar, mRNA ve viral vektör aşılarının nasıl çalıştığına bağlı olarak, gebeler, fetüs veya yenidoğanlar için risk oluşturma olasılı̆̆ının düşük olduğuna inanmaktadır'. Çin ve Hindistan'da geliştirilen inaktive COVID-19 aşıları adjuvan içerirler. Adjuvan aşılardan genellikle güvenlik verilerinin eksikliği nedeniyle gebelikte kaçınılır. Ancak bu teorik endişe, hastanın gebelik sirasında SARS-CoV-2'ye maruz kalma riski ve bilinen COVID-19 riskleri ile dengelenmelidir. Hayvan çalıșmalarından elde edilen veriler aşılanmış gebelerde zararlı etkiler göstermemiştir. Hastalık Kontrol ve Önleme Merkezi'nin (CDC) verilerine göre de gebelikte COVID-19 aşısı olan kadınlarda gebelik ile ilgili olumsuz durumlarda (düşük, konjenital anomali, fetal büyüme geriliği, erken doğum, ölü doğum vb) genel obstetrik populasyona göre bir artış izlenmemiştir ${ }^{7-9}$.

Bu veriler ışığında tüm gebelerin COVID-19 aşısı olmaları önerilmektedir. Bu öneri, gebelik sırasında COVID-19 aşılarının güvenliği ve etkinliği ile ilgili giderek daha fazla güven veren verilere dayanmaktadır.

COVID-19 aşıları, gebelikte rutin olarak uygulanan diğer aşılarla (örn. influenza, Tdap) aynı zamanda uygulanabilir; aşılar arasında bir ayrim periyodu gereksizdir. Anti-D immünoglobulin, aşılara karşı immün yanıtı etkilemez. Bu nedenle alloimmünizasyonun önlenmesi için uygulama zamanlaması standart klinik protokollere göre yapılmalıdır.

İki dozluk bir COVID-19 aşı serisinin ilk dozu alındıktan sonra gebelik oluşursa, ikinci doz, üretici tarafından gebe olmayan kişiler için belirtilen zamanda uygulanmalıdır. COVID-19 aşılarının doğurganlı̆̆ $\quad$ etkilediği düşünülmemektedir, onaylanmış herhangi bir COVID-19 aşısı yaptırmadan önce gebelik testi yapılması gerekli değildir. Ayrıca aşılamadan sonra gebeliğin ertelenmesi gerekli değildir ${ }^{10}$.

\section{KLİNIK BULGULAR}

Belirti ve semptomlar - Tüm gebe hastalar, özellikle de kesin veya şüpheli tanısı olan hastalarla temas öyküleri varsa, COVID-19 semptom ve bulguları açısından takip edilmelidir (Tablo I). Gebelerde en yaygin semptomlar11: Öksürük $(\% 50,3)$, baş ağrısı (\%42,7), kas ağrıları (\%36,7), ateş (\%32), boğaz ağrısı $(\% 28,4)$, nefes darlığı $(\% 25,9)$, tat veya koku kaybı $(\% 21,5)$. 
Tablo I: COVID-19 ile İlişkili Semptomlar

\begin{tabular}{|l|l|l|}
\hline Öksürük & Boğaz ağrısı & $\begin{array}{l}\text { Rinore/nazal } \\
\text { konjesyon }\end{array}$ \\
\hline Ateş & İshal & Titreme \\
\hline Miyalji & Bulantı/Kusma & Yorgunluk \\
\hline Başağrısı & Anosmi & Konfüzyon \\
\hline $\begin{array}{l}\text { Dispne (yeni veya } \\
\text { kötüleşen) }\end{array}$ & Tat duyu kaybı & Göğüs ağrısı \\
\hline $\begin{array}{l}\text { Gebelerin çoğu asemptomatiktir, ancak } \\
\text { asemptomatik iyi }\end{array}$ \\
\hline
\end{tabular}
tanımlanmamıștır. Yapılan bir incelemede, gebelerde COVID-19 enfeksiyonlarının \%95'i asemptomatikti ve takip boyunca \%59'u asemptomatik olarak kalmıştır ${ }^{12}$.
COVID-19'un klinik belirtilerinden bazıları normal gebelik semptomlarıyla (örneğin yorgunluk, nefes darlığı, burun tıkanıklığı, bulantı/kusma) örtüşmektedir. $\mathrm{Bu}$ nedenle ateşi olmayan semptomatik bir gebe COVID-19 açısından dikkatli bir şekilde değerlendirilmelidir.

Görüntüleme ve laboratuvar bulguları COVID-19'u olan gebelerde laboratuvar ve görüntüleme bulguları genellikle gebe olmayanlar ile benzerdir (Tablo II): Artmış Creaktif protein düzeyi (\%49), lenfopeni (\%33), lökositoz (\%26), artmış prokalsitonin düzeyi (\%23), anormal karaciğer enzimleri $(\% 15,4)$, trombositopeni $(\% 6,6)^{13}$.

Tablo II: Ciddi COVID-19 ile İlişkili Laboratuar Bulguları

\begin{tabular}{|l|l|}
\hline Anormallik & Muhtemel Eşik Değer \\
\hline D-dimer & $>1000 \mathrm{ng} / \mathrm{mL}$ (Normal aralık:<500 ng/mL) \\
\hline CRP & $>100 \mathrm{mg} / \mathrm{L}$ (Normal aralık: $<8.0 \mathrm{mg} / \mathrm{L})$ \\
\hline LDH & $>245$ units/L (Normal aralık: $110-210$ units/L) \\
\hline Troponin & $>500$ mormalin üst limitinin 2 katı (Normal aralı: kadınlarda 0-9 ng/L; erkeklerde 0-14 ng/L) \\
\hline Ferritin & $>$ Normalin üst limitinin 2 katı (Normal aralık: 40-150 units/L) \\
\hline CPK & $<800 /$ microL (Normal aralık $\geq 21$ yaş: 1800-7700/ microL) \\
\hline Mutlak lenfosit sayısı & \\
\hline
\end{tabular}

CRP: C- reaktif protein; LDH: Laktat dehidrogenaz; CPK: kreatin fosfokinaz

Lökositoz gebelikte normalde de olabilir. Diğer laboratuvar bulgularının bazıları ise gebelikle ilişkili bozukluklarda görülebilir (örneğin; şiddetli preeklampside trombositopeni ve karaciğer enzim düzeylerinde artış).

Erken veya hafif hastalıkta akciğer grafileri normal olabilir. Toraks bilgisayarlı tomografisinde (CT) en sık karşılaşılan pulmoner bulgular; buzlu cam opasiteleri (\%77), posterior akciğer tutulumu (\%73), multilobar tutulum (\%72), bilateral akciğer tutulumu (\%69), periferik dağılım (\%68) ve konsolidasyon $(\% 41)^{14}$.

Hastalık şiddetinin sınıflandırılması ABD'de Ulusal Sağlık Enstitüleri (NIH), gebe olmayanlarda hastalık şiddetini aşağıdaki şekilde sınıflandırmıştır ${ }^{15}$ :

- Asemptomatik hastalık - SARS-CoV-2 için pozitif test, ancak semptom yok.

- Hafif hastalık - Nefes darlı̆ğ olmaksızın herhangi bir belirti ve semptom (örn. ateș, öksürük, boğaz ağrısı, halsizlik, baş ağrısı, kas ağrısı). 
- Orta derecede hastalık - Klinik değerlendirme veya görüntüleme ile alt solunum yolu hastalığının varlığı ve oksijen saturasyonunun (SaO2) $\geq \% 94$ 'tür.

- Ciddi hastalık - Solunum sıklığı $>30$ solunum /dakika, $\mathrm{SaO} 2<\% 94$ veya akciğer infiltratları > $\% 50$.

- Kritik hastalık - Solunum yetmezliği, septik şok ve/veya multiorgan disfonksiyonu.

\section{GEBELIKTTE PROGNOZ}

Maternal Prognoz - Yayınlanan çalışmalar gebeliğin SARS-CoV-2 enfeksiyonuna duyarlılığ artırmadığı, ancak aynı yaştaki gebe olmayan kadınlara kıyasla COVID-19'un klinik seyrini kötüleștirdiği bildirilmiştir ${ }^{11}$.

Enfekte gebelerin çoğu (> yüzde 90) hastaneye yatmadan iyileşse de, hızlı klinik bozulma meydana gelebilir. Semptomatik gebe hastalar, üreme çağındaki semptomatik gebe olmayan kadınlara kıyasla ciddi hastalık ve ölüm riski altında görünmektedir. Gebelikte ciddi hastalık ve ölüm için risk faktörleri arasında ileri yaş (özellikle $\geq 35$ yaş), obezite ve diğer komorbiditeler ( hipertansiyon, diyabet vb.) yer alır.

Şüpheli veya kesin COVID-19 tanısı olan 64.000'den fazla gebeyi içeren 192 çalışmanın sistematik bir incelemesinde; hastaların $\% 17,4$ 'ünde pnömoni görülmüş, $\% 17.1$ 'i oksijen desteği almış, \%13,4'ünde akut solunum sıkıntısı sendromu (ARDS) meydana gelmiş, $\% 11,3$ 'ünde şiddetli hastalık görülmüș, $\% 3.3$ 'ü yoğun bakım ünitesine yatırılmış, \%1,6'sı invaziv ventilasyon, $\% 0,11$ 'i ekstrakorporeal membran oksijenasyonu (ECMO) almış ve ölüm $\% 0,8$ oranında görüldüğ̈̈ bildirilmiștir ${ }^{12}$.

Komplikasyonlar - COVID-19'un maternal komplikasyonları:

- Solunum bozuklukları - Pnömoni, solunum yetmezliği, ARDS
- Kardiyak bozukluklar (aritmiler, akut kardiyak hasar)

- Tromboembolik komplikasyonlar

- Sekonder enfeksiyonlar

- Akut böbrek yetmezliği

- Nörolojik bozukluklar - Baş ağrısı, baş dönmesi, kas ağrısı, bilinç değişikliği, koku ve tat bozuklukları, halsizlik, inme, nöbetler

- Cilt hastalıkları - Morbiliform döküntü; ürtiker; akral lezyonlar; vasküler lezyonlar ve veziküler lezyonlar

- Gastrointestinal ve karaciğer bozuklukları

- Psikiyatrik hastalık (örneğin, anksiyete bozuklukları, depresif bozukluklar, uykusuzluk, travma sonrası stres bozukluğu)

Ciddi COVID-19'lu bazı hastalarda, kritik ve ölümcül hastalıklarla ilişskilendirilen abartılı bir inflamatuar yanıtın (sitokin firtınası) olduğu bilinmektedir. Gebeliğin normal immünolojik değişikliklerinin bu yanıtın oluşumunu ve seyrini etkileyip etkilemediği bilinmemektedir.

Konjenital enfeksiyon -Vertikal geçişin sıklığı (in utero, intrapartum, erken postnatal dönem) henüz tam olarak bilinmemektedir. İn utero bulaşma tipik olarak hematojen yolla, bazen de assendan yolla gerçekleşir. COVID-19 hastalarında viremi oranlarının yüksek olmadığ nedenle in utero bulașmanın yaygın olmadığı düşünülmektedir ${ }^{16}$. Bildirilen raporlar vajinal sekresyonlarla temas sonucu intrapartum bulaşmanın da nadir olduğunu düşündürmektedir ${ }^{17}$. Öte yandan, anne dışkısında viral bulaşma yaygındır, bu nedenle perinenin dişkı ile kontaminasyonu teorik olarak intrapartum bulaşmanın bir kaynağ olabilir, ancak sezaryenin koruyucu etkisine dair bir kanıt yoktur. Doğum sonrası bulaşma, anne sütü veya enfekte bir anneden (veya başka bir bakıcıdan) bebeğine solunum veya diğer bulaşıcı salgılar yoluyla gerçekleşebilir. 
Konjenital enfeksiyon tanı kriterleri18:

- SARS-CoV-2 enfeksiyonu olan bir annede, membranların yırtılmasından önce alınan amniyotik sıvı veya,

- Doğumdan sonraki ilk 12 saat içinde alınan yenidoğan kanı veya umblikal kord kanında polimeraz zincir reaksiyonu ile SARS-CoV-2 tespit edilmesi.

\section{Gebelik ve Yenidoğan Sonuçları}

Gebelikte geçirilen COVID-19'un düşük riskini arttırmadığı ancak birinci ve ikinci trimester enfeksiyonlarına ilişkin verilerin sınırlı olduğu bildirilmektedir ${ }^{19}$.

Erken doğum ve sezaryen doğum oranlarının COVID-19'lu gebelerde arttığı bildirilmiştir ${ }^{13}$. Birçok gebenin, ciddi maternal solunum yolu hastalığının doğumla iyileştirileceği inancıyla planlı sezaryen ile doğurtulduğu görülmektedir; ancak, bu hipotez kanıtlanmamıştır.

Gebelik sırasında SARS-CoV-2 enfeksiyonuna ilişkin gözlemsel çalışmaların bir meta-analizi, enfekte hastalarda preeklampsi gelişme olasılığının \%62 daha yüksek olduğunu bildirmiştir ${ }^{20}$.

Konjenital anomaliler için artmış bir risk bildirilmemiştir ${ }^{19}$. 12 ülkeden SARS-CoV-2 enfeksiyonu olan gebe hastalardan elde edilen verilerin analizi, ölü doğum oranlarının ulusal nüfusa dayalı veriler ile benzer olduğunu $(\% 0,4-0,6)$ bildirmiştir ${ }^{21}$.

COVID-19 tanılı annelerden doğan bebeklerin \%95'ten fazlası doğumda asemptomatiktir. Bazı annelerin yenidoğanlarında hafif enfeksiyon semptomları (solunum desteği gerektirmeyen) gelişmiştir. $\mathrm{Bu}$ vakaların çoğunda bulaşma yolunun anneden yenidoğana solunum damlacıkları ile olduğu düşünülmüştür. 12 ülkeden elde edilen verilerin analizine göre SARS-CoV-2 enfeksiyonu olan gebelerde, tüm nedenlere bağlı erken neonatal ölüm oranları \%0,2- 0,3 olarak bildirilmiş; bu oran, COVID-19 öncesi verilerle benzerdir ${ }^{21}$. İsveç'te yapılan bir çalışmada pandemi sırasında SARS-CoV-2 pozitif annelerin bebeklerinde, enfekte olmayan annelerin bebeklerine klyasla solunum problemi oranlarında küçük bir artış tespit edilmiştir (\%2,8'e karşı \%2). Aynı çalışmada yenidoğan yoğun bakıma yatış oranı ise SARSCoV-2 pozitif annelerin bebeklerinde \%11,7 iken enfekte olmayan annelerin bebeklerinde $\%$ 8,4 olarak bildirilmiştir ${ }^{22}$.

\section{TANIYA YAKLAŞIM}

Gebelikte tanıya yaklaşım genel popülasyondakine benzerdir. Hastalar bir sağlık kuruluşuna giriş yapmadan önce COVID 19 ile uyumlu klinik belirtiler (örneğin öksürük, ateş, miyalji, boğaz ağrısı, nefes darlığı, tat ve/veya koku kaybı) açısından taranmalıdır. Enfeksiyonun yaygın olduğu bölgelerde, eğer mümkünse, tüm hastaların doğum eylemi ve doğum sırasında hızlı bir SARS-CoV-2 testi ile test edilmesinin makul olduğu düşünülmektedir. Planlanmış indüksiyonlar ve sezaryen doğumlar için hastalar, hastaneye yatıştan sonraki 72 saat içinde test edilebilirler.

Pozitif RT-PCR testi COVID-19 enfeksiyonunu doğrular. Negatif testte ise özellikle semptomların başlangıcının ilk 4 günü içindeyse yanlış negatiflik ihtimali akla gelmelidir ve gebelerde de bu durum gösterilmiştir. Negatif test sonrası şüphe devam ediyorsa ilk testten 24 saat sonrası ile birkaç gün içinde yeni test yapılmalıdır. İki negatif test genel olarak COVID-19'u ekarte etmek için yeterli kabul edilmektedir ${ }^{23}$.

COVID-19 nedeniyle yatan hastalarda pulmoner komplikasyonların ve akciğer tutulumunun ilk değerlendirmesi için bir akciğer radyografisi yeterlidir. Tek bir gögüs radyografisi 0.0005 ila 0.01 mGy'lik çok düşük bir fetal radyasyon dozu taşır. Eğer endikasyon varsa akciğer tomografisi (CT) de güvenle çekilebilir. Akciğer tomografisi için de fetal radyasyon dozu düşüktür ve fetal anomali veya gebelik kaybı riski ile ilişkisi gösterilmemiştir. Bazı yazarlarlar tarafından 
semptomatik gebelerde pnömoninin hızlı teşhisi için obstetrik tarama ile eş zamanlı akciğer ultrasonografisi önerilmektedir ${ }^{24}$.

\section{AYIRICI TANI}

Diğer enfeksiyonlar - COVID-19'un erken semptomları, diğer birçok viral ve bakteriyel solunum yolu enfeksiyonuna benzer (örn. influenza, adenovirüs, Mycoplasma pnömonisi). Grip toplumda yaygınsa, SARS-CoV-2 için test yapılırken grip için de test yapılması mantıklıdır, çünkü sonuç tedaviyi etkileyebilir.

Preeklampsi, HELLP sendromu - Gebelerde, COVID-19 ile ilgili bazı laboratuvar anormallikleri (yüksek karaciğer enzim seviyeleri, trombositopeni), şiddetli preeklampsi ve HELLP sendromuyla örtüşmektedir. Otoimmün hemoliz, uzamış protrombin zamanı, yükselmiş $\mathrm{D}$ dimer, prokalsitonin ve C-reaktif protein (CRP) seviyeleri, pozitif lupus antikoagülan taraması ve düşük fibrinojen seviyeleri komplike COVID19 vakalarında da gözlemlenebilir. Baş ağrısı, akut serebrovasküler hastalık ve nöbetler, COVID-19'un nörolojik belirtileri olabileceği gibi, şiddetli özelliklere sahip preeklampsi veya eklampside de görülebilir ${ }^{13}$. Ayırıcı tanıda akut hipertansiyonun varlığı yardımcı olabilir. Hipertansiyon preeklampsi ve HELLP sendromunda sık görülürken COVID-19'da beklenen bir bulgu değildir. Hem şiddetli COVID-19 hem de preeklampsi ile ilişkili klinik bulguları olan gebeler için perinatoloji konsültasyonu istenmelidir.

\section{PRENATAL BAKIM}

\section{Enfekte olmayan gebeler}

Riski olmayan gebelerin rutin doğum öncesi bakımı gereklidir ve planlanmalıdır. Asemptomatik hastalarda ilk üç ay ultrasonografi taraması ve 18-22 hafta arası ayrıntılı ultasonografi değerlendirmesi mümkün olduğunca yapılmalıdır. Yüksek riskli gebelerde, fetal durum aksini gerektirmediği sürece gereğinden fazla ultasonografik muayene kesinlikle yapılmamalıdır. Kadın hastalıkları ve doğum uzmanı annenin ve fetusun durumuna göre yapılacak ultrasonografi incelemelerinin sıklığına karar vermelidir ${ }^{25}$.

\section{Şüpheli temaslı gebeler}

Gebenin şüpheli temas halinde başka bir nedenle hastaneye yatışı gerekmiyorsa 14 gün boyunca mümkün olduğu kadar evde kalması ve toplu alanlardan uzak durması istenir. Toplu alanlara gitmesinin zorunlu olduğu hallerde ise tıbbi maske takması istenir. Eve ziyaretçi kabul etmemesi, odanın iyi havalandırılması, ev halkının diğer üyelerinden mümkün olduğunca ayrı kalınması, farklı havlular, farklı tabak çanak ve mutfak eşyası kullanılması ve farklı zamanlarda yemek yemesi önerilmektedir. Şüpheli bir temas sonrası gerekli izolasyon süresi (14 gün) dolana kadar acil durumlar dışında muayene ertelenebilir. Gebeyle iletişim kurularak genel durumu hakkında bilgi alınmalı, bilgilendirme yapilmalı, randevu zamanı bildirilmelidir ${ }^{3,25}$.

\section{Enfekte gebeler}

Asemptomatik gebeler - Gebelerde komplike olmayan COVID-19 enfeksiyonu için tedavisiz izlem seçeneği öncelikle düşünülmelidir. Asemptomatik gebelerin ciddi hastalık geliştirme riskleri değerlendirilmeli, solunum yetmezliği (hızla ortaya çıkabilir) açısından takip edilmeli, enfeksiyon kontrolü ve hastanın uygun izolasyonu sağlanmalıdır.

Semptomatik hastalar - Semptomatik hastaların klinik bakımı, hastalığın ciddiyetine, altta yatan tıbbi komorbiditelere, eşlik eden gebelik komplikasyonlarına bağlıdır. Olası tanı almış olan gebelerde risk faktörü varsa veya ağır seyir söz konusu ise tedavi verilmesi düşünülmelidir. Favipiravir gebelerde ve emzirenlerde kullanılmamalıdır. Gebenin şiddetli COVID-19 nedeniyle hastaneye yatışı 
gerekiyorsa, multidisipliner bir ekip en uygun yerin belirlenmesine yardımcı olmalıdır ${ }^{25,26 .}$

\section{EVDE BAKIM}

Şüpheli veya kesin COVID-19 tanılı gebelerin çoğunda (en az \%86’l) hastalık hafif seyreder. Obstetrik problemler (Örn; preterm eylem), maternal durumda hızlı bozulma endișesi, hastaneye hızlı bir şekilde ulaşamama veya kendi kendini izole edememe gibi durumlar dışında hastane düzeyinde bakım gerekmez.

Evde bakım, diğer akut viral hastalıklar için önerilenlere benzer şekilde genellikle destekleyicidir. Hidrasyon, yeterli dinlenme ve tolere edilince daha ileri aktivite ile sık ambulasyon tavsiye edilir.

\section{Acil tıbbi bakım ne zaman istenmeli?}

- Kötüleşen nefes darlı̆̆ı,

- Uygun asetaminofen kullanımına rağmen aralıksız ateş $>39^{\circ} \mathrm{C}$,

- Oral hidrasyonu ve ilaçları tolere edememe,

- Kalıcı plöritik göğüs ağrısı,

- Konfüzyon,

- Obstetrik komplikasyonlar (örneğin preterm eylem, vajinal kanama, membran rüptürü),

- Solunum hizı $\geq 20$ - 24 solunum/dakika ve/veya kalp hızı >100 atım/dakika

$\mathrm{Bu}$ belirtiler klinik bozulma riski taşıyan hastalar için uyarı işaretleridir.

Üçüncü trimesterdeki gebeler, fetal hareket sayımı yapmalı ve fetal harekette azalma olduğunda bildirmelidirler.

\section{HASTANEDE BAKIM}

\section{Gebe COVID-19 hastaları için hastaneye yatış endikasyonları 27 :}

- Hastaneye yatış gerektiren komorbid bir durum (örn. hipertansiyon veya diyabet, preeklampsi, doğum öncesi membran rüptürü, uterin kanama)
- Asetaminofen kullanımına rağmen ateş $>39^{\circ} \mathrm{C}$ (sitokin firtınası sendromu için endişe uyandıran)

- Orta veya şiddetli belirti ve semptomlar (örneğin, oksijen satürasyonu < yüzde 95, solunum frekansı dakikada $>30$ )

- Kritik hastalık - Solunum yetmezliği, uygun hidrasyona rağmen hipotansiyon ve/veya yeni başlamış hedef organ disfonksiyonu (örneğin, zihinsel durum değişiklikleri, karaciğer veya böbrek yetmezliği, kardiyak disfonksiyon).

Ciddi hastalık, ek oksijen gereksinimi olan komorbiditeler veya kritik hastalık nedeni ile hastaneye yatırılan gebe hastalar, obstetrik servisleri ve yetişkin yoğun bakım ünitesi olan III. veya IV. basamak bir hastanede multidisipliner bir ekip tarafından takip edilmelidir.

Maternal solunum desteği -Gebelikte maternal oksijen satürasyonu (SaO2) $\geq \% 95$ olarak sağlanmalıdır, eğer SaO2 \%95'in altına düşerse arteryel kan gazı alınarak parsiyel oksijen basıncı (PaO2) bakılmalıdır. Anneden bebeğe yeterli oksijen gradyenti sağlanabilmesi açısından $\mathrm{PaO} 2>70 \mathrm{mmHg}$ olmalıdır. Hipokseminin derecesine göre inhale oksijen verilebilir. Yeterli oksijenasyonu sağlamak amacıyla yüksek akım oksijenizasyon, entübasyon veya mekanik ventilasyon hatta Ekstrakorporeal Membran Oksijenasyonu (ECMO) kullanılır. Dünya Sağlık Örgütü (WHO), hasta stabil hale geldiğinde maternal oksijen satürasyonunu \%92 ila \%95 arasında tutmayı önermektedir ${ }^{28}$.

Venöz tromboembolizm profilaksisi COVID-19 enfeksiyonu tromboembolik olay riskinde artışa neden olabilir. Gebeliğin hiperkoagülabiliteye yatkınlık oluşturduğu da göz önünde bulundurularak kontrendike bir durum mevcut değilse, hastanede yatan tüm gebelere uygun dozlarda düşük moleküler ağırlıklı heparin (DMAH) ile rutin farmakolojik venöz tromboemboli profilaksisi önerilir. 
Tedavi sonrasinda taburcu olduğunda ek risk faktörü aranmaksızın profilaksiye 7-14 gün devam edilir ${ }^{26}$.

Steroid kullanımı- Fetal akciğer
maturasyonu amacıyla betametazon veya
deksametazon, gebeliğin 24-34. haftaları
arasında olan gebeliklerde rutin dozda, ilgili
endikasyonlar dahilinde uygulanmalıdır.
Şiddetli COVID-19 klinik bulguları olan ve
bunun tedavisi amaciyla yüksek doz steroid
uygulanması gereken olgularda ise, fetal akciğer
maturasyonu indüksiyonuna yönelik
betametazon/deksametazon uygulaması
sonrasında prednizolona veya hidrokortizona
geçilmelidir26.

\section{Asetaminofen}

ve

Nonsteroid antiinflamatuar ilaçların (NSAï) kullanımı Analjezik ihtiyacı olan gebelerde öncelikli olarak mümkün olan en düşük dozda asetaminofen tercih edilmelidir. Illk trimester de dahil olmak üzere gebelikte asetaminofen kullanımının genel olarak güvenli olduğu ve yüksek ateş ile ilişkili gebelik risklerini azaltabileceği gösterilmiștir. Nonsteroid antiinflamatuar ilaçlar (NSAiI) da klinik olarak endikasyon dahilinde COVID-19 hastalarında ateş ve ağrı tedavisinde kullanılabilir. Gebelik haftasına bağlı potansiyel fetal toksisite (örneğin, oligohidramnios, duktus arteriyozusun erken kapanması) gözönünde bulundurularak en düşük etkili doz 48 saatten daha kısa bir süre kullanılabilir29. Preeklampsinin önlenmesi için düşük doz aspirin gebelik boyunca güvenlidir. COVID-19 tanısı almış ve düşük doz aspirin kullanım endikasyonu olan gebelerde, ilaç kullanım kararı hasta özelinde verilmelidir.

Tokoliz - COVID-19 enfeksiyonu saptanan olgularda tokoliz uygulaması tartışmalı olup, tokoliz uygulanması gereken olgularda ise ilk seçenek nifedipin olmalıdır. Teorik olarak ACE2 reseptör etkileşimi nedeniyle indometazin kullanımından kaçınılmalıdır. Indometazin, hipoksiye karşı koruyucu mekanizmayı bozarak hipoksik pulmoner hipertansiyon durumunu ağırlaştırabilir.

Magnezyum Sülfat kullanımı -COVID-19 nedeniyle solunum sıkıntısı olan entübe edilmemiş hastalarda, maternal nöbet profilaksisi ve/veya neonatal nöroproteksiyon amaçlı magnezyum sülfat verilmesi gerekiyorsa özellikle dikkat edilmelidir. Yüksek magnezyum seviyeleri (10-13 $\mathrm{mEq} / \mathrm{L})$ solunum felcine neden olabilir. Ayrıca COVID-19 ile ilișkili akut böbrek hasarı olan hastalarda, ilacın kesilmesi yerine doz ayarlayıcı magnezyum sülfat önerilmektedir. Entübe edilmiş, mekanik olarak ventile edilen hastalarda magnezyumla ilişkili solunum toksisitesi belirtileri gözlemlenmeyecektir; bu nedenle kardiyak aritmiler veya arrest ciddi toksisitenin ilk belirtisi olabilir. Maternal nöbet profilaksisinde ve /veya neonatal nöroproteksiyon amaçlı magnezyum sülfatın kullanımına mümkünse perinatoloji, göğüs hastalıkları ve yoğun bakım uzmanı ile birlikte karar verilmesi önerilir ${ }^{26}$.

Antiviral ilaç tedavisi -Salgının ilk dönemlerinde yapılmış çalışmalarda gebe olmanın ağır seyirli COVID-19 için fazladan risk yaratmadığı bildirilmiş olmakla birlikte, son dönemde yapılmış bazı çalışmalarda gebelerde enfeksiyonun daha ağır seyredebileceği görülmüștür. Gebelerde komplike olmayan COVID-19 enfeksiyonu için tedavisiz izlem seçeneği öncelikle düşünülmelidir. Olası tanı almış olan gebelerde risk faktörü varsa veya ağır seyir söz konusu ise tedavi verilmesi düşünülmelidir. Gebelerde etkinliği ve güvenilirliği kanıtlanmış bir tedavi seçeneği bulunmamaktadır. COVID-19'lu gebelerde antiviral tedavi kararı, hastanın durumuna göre ilgili hekim tarafından hastayla birlikte alınmalıdır ${ }^{30}$.

Remdesivir: Remdesivir SARS-CoV 2'ye ve coronavirüsler ile ilişkili (SARS ve MERS-CoV) diğer enfeksiyonlara karşı in vitro etkinliği gösterilen yeni bir nükleotid analoğudur. Antiviral tedavi endikasyonu olan şiddetli 
COVID-19'lu gebelerde Remdesivir önerilmektedir ${ }^{31}$. Ebola ve Marburg virüsü hastalığı olan gebelerde kullanılmış ve fetal toksisite bildirilmemiştir.

COVID-19 tanısı almış gebelerde; yeterli veri olmamakla birlikte aşağıdaki tedaviler de denenmektedir:

-İmmün plazma tedavisi: Bazı gebe hastalarda denenmiştir. Ancak klinik yararının olmadığı düşünülmektedir.

-Tosilizumab,

-Rekombinant IL-1 reseptör antagonisti (Anakinra) ${ }^{30}$.

\section{Fetal izlem}

Yaşamla bağdaşan gebelik haftasının üzerindeki hastalarda fetal izlem gerekir. Fetal testlerin sıklığı gebelik haftasına, maternal vital bulgular ve oksijenizasyonun stabilitesine, diğer maternal komorbiditelere bağlıdır. Stabil olmayan hastalarda devaml fetal monitorizasyon gerekebilir. Oksijen saturasyonu stabil olan hastalarda günde bir veya iki kez non-stres test (NST) yapılabilir.

\section{Doğum zamanlaması}

Doğum zamanlaması, annenin durumuna, maternal komorbiditelere ve gebelik haftasına göre bireyselleştirilmelidir.

\section{Hafif veya asemptomatik hastalık:}

37. gebelik haftasından önce COVID-19 pozitifliği doğum için bir endikasyon değildir ve doğum rutin obstetrik endikasyonlarda düşünülmelidir.

37- 39. gebelik haftaları arasında COVID-19 pozitif asemptomatik veya hafif semptomatik bir kadında, doğum için başka bir endikasyon yoksa, PCR sonucunun pozitif olduğu kaydedildikten 14 gün sonrasına kadar veya semptomların bașlamasından 7 gün sonrasına ve semptomların gerilemesinden 3 gün sonrasına kadar beklenebilir. Bu seçenek, sağlık çalışanlarının ve yenidoğanın SARS-CoV-2'ye maruz kalma riskini azaltacaktır.

39. gebelik haftasında veya sonrasında COVID19 pozitif asemptomatik veya hafif semptomatik bir kadında, doğumun maternal durumun kötüleşme riskini azalttığı düşünülmektedir ${ }^{27}$.

Doğum şekline rutin endikasyonlara göre karar verilmelidir. Doğum sırasında COVID-19 hastalarına doğum eylemi, doğum ve doğum sonrası boyunca maske takmaları talimatı verilmeli ve sağlık çalışanları tarafından uygun kişisel koruyucu ekipman kullanılmalıdır.

\section{Ciddi / Kritik hastalık}

Kritik hastalarda dikkate alınması gereken çok sayıda sorun olabileceğinden doğum zamanlaması olguya göre belirlenmelidir ${ }^{23,32}$. Doğumun hastanın solunum problemlerini rahatlatıp rahatlatmayacağı veya akut dönemde doğum odasında postnatal bulaş riski bilinmemektedir. Bununla birlikte pnömonisi olan hastalarda gebelikte fizyolojik olarak gelişen artmış oksijen tüketimi ve rezidüel kapasitedeki azalma maternal durumun bozulmasını hızlandırabilir ${ }^{33}$.

Hastaneye yatırılmış, pnömonisi olan ancak entübe olmayan hastalarda bazı otoriteler 3234 haftanın üzerindeki gebelerde doğumun düşünülmesini önermektedir. $\mathrm{Bu}$ önerinin temeli, pulmoner durumun bozulmasından ve annenin hipoksisine bağlı gelişebilecek fetal durum bozulmasından önce doğumun gerçekleştirilmesine dayanmaktadır. Çoğu otorite, çok erken doğmuş bebeklerin bilinen morbidite ve mortalitesi göz önüne alındığında, ikinci haftada annenin durumu kötüleşebilse de, 32. haftadan önce doğumu savunmamaktadır.

Entübe gebe hastalarda doğum zamanlaması daha zor belirlenir. Bazl otoriteler 32-34. haftadan sonra hasta stabil ise gebelikle ilişkili gelişebilecek ek problemlerden korunma adına doğum önermektedir. Bununla birlikte doğum 
maternal durumu daha da bozabilir. Fetal viabilite gelişmiş ancak 32 haftadan küçük olgularda maternal durum stabil kaldığı sürece fetal monitorizasyonla birlikte maternal izlem önerilmektedir. Bazı durumlarda (örneğin, dirençli COVID-19 ile ilişkili solunum yetmezliği) maternal ECMO gerekli olabilir. ECMO mevcut değilse, hastanın ECMO bulunan bir merkeze nakledilmesi düşünülmelidir ${ }^{34}$.

\section{EYLEM VE DOĞUM YÖNETIMİ}

\section{Enfeksiyon kontrol önlemleri:}

- Doğum için başvuran tüm hastalar semptom ve bulgular açısından (ateş, yeni başlayan öksürük, nefes darlığı, boğaz ağrısı, kas ağrısı, burun akıntısı, koku ve tat kaybı) veya COVID19 tanılı olgularla temas hikayesi açısından doğum odasına alınmadan önce sorgulanmalıdır.

- Doğum ünitelerine asemptomatik ve presemptomatik olguların başvurabileceği de unutulmamalıdır. $\mathrm{Bu}$ nedenle enfeksiyonun yaygın olduğu bölgelerde eğer imkan varsa doğum için başvuran tüm hastalara hızlı SARSCoV-2 testi yapılmalıdır.

- Test sonucu pozitif bir hastada uygun enfeksiyon kontrol hazırlıkları yapılmalıdır (örneğin, doğum için en uygun oda belirlenmeli, uygun kişisel koruyucu ekipmanın mevcut olduğundan emin olunmalı).

- COVID-19'lu gebe hastaların bakımı özel banyosu olan, iyi havalandırılan, tek kişilik bir odada (mümkünse negatif basınçlı oda) yapılmalıdır. Sağlık çalışanları tam kişisel koruyucu ekipman (KKE) (önlük, eldiven, N95 maske, yüz siperi) kullanmalıdır.

- Gebe COVID-19 hastalarının eylem ve doğum sırasında devamlı cerrahi maske takmaları sağlanmalıdır. Bununla birlikte özellikle aktif ıkınma sırasında hastanın maske ile takip edilmesi zor olabilir.

- Aktif eylem sırasında hastanın güçlü bir şekilde nefes verdiği anlarda maskenin etkinliğinin azalabileceği akılda tutulmalıdır. $\mathrm{Bu}$ nedenle sağlı çalışanları N95 maske kullanmalıdır.

\section{Doğum Şekli}

Hafif veya asemptomatik hastalarda COVID-19, planlanan doğum şeklini değiştirmek için bir endikasyon değildir 35 . Sezaryen doğum standart obstetrik endikasyonlarla gerçekleştirilmelidir. Sezaryen doğumun vertikal geçişi azaltacağına dair kanıt mevcut değildir ${ }^{36}$.

Şiddetli veya kritik COVID-19 hastalarında, entübe ve kritik hastaları akut dekompansasyonu ile ilgili endişelerden dolayı sıklıkla sezaryen doğum yapılır. Doğumun şekli veya yeri ne olursa olsun (örneğin, doğum ünitesi, ameliyathane, yoğun bakım ünitesi) multidisipliner bir bakım ekibi mevcut olmalıdır (örneğin, yoğun bakım uzmanları, perinatolog, neonatolog, yenidoğan hemşirelik desteği, pediatri ve tıbbi disiplinler).

\section{Analjezi ve Anestezi}

COVID-19 tanılı hastalarda doğumda nöroaksiyel anestezi kontrendike değildir ve doğum eylemindeki hastalarda birçok avantajı mevcuttur; iyi düzeyde analjezi sağlar, ağrı ve anksiyeteden kaynaklanan kardiyopulmoner stresi azaltır, olası bir acil sezaryende genel anestezi ihtiyacını ortadan kaldırır. Obstetrik Anestezi ve Perinatoloji Cemiyeti, doğum analjezisinde nitrik oksit kullanımını bu sistemlerin temizlenmesi ve filtrelenmesi ile ilgili yeterli veri olmadığından ve olası aerosol oluşumu nedeniyle önermemektedir 5 .

\section{Doğum Eylemi Yönetimi}

Kesin veya şüpheli COVID-19 olgularında hastalık asemptomatik veya hafifse eylem yönetiminde herhangi bir değişikliğe gerek yoktur. Kişisel temas ve hastanede kalış süresi mümkün olduğunca kısa tutulmalıdır. Servikal olgunlaşma gereken hastalarda balon kateter ile mekanik olgunlaşma kullanılabilir. Yatırılan 
hastalarda çift ajan kullanımı (mekanik ve mizoprostol / mekanik ve oksitosin) indüksiyon-doğum aralığını kısaltmaktadır. Güven vermeyen fetal kalp hızı paternlerinin sıklığı arttığı için şüpheli ve kesin olgularda sürekli elektronik fetal monitorizasyon önerilmektedir. Amniyotik sıvl ve vajinal sekresyonlarda SARS-CoV-2 nadiren saptanmıștır. $\mathrm{Bu}$ nedenle membran rüptürü rutin endikasyonlarla yapılabilir ancak bu konudaki veriler yetersizdir ${ }^{37}$. İntrapartum oksijenin fetal faydası gösterilmediğinden bu hastalarda maternal oksijen tedavisi uygulanmamalıdır. Uygulanan hastalarda maternal solunum yolu ve sekresyonlarla temas halinde olan nazal kanül ve maskelere dokunulması kontaminasyon riskini arttırır.

\section{Doğum Yönetimi}

Doğumun ikinci evresinin kısa tutulması önerilmektedir. COVID-19 hastalarında geç kord klemplemenin fetal bulaşı arttırdığına dair kanıt olmamakla birlikte bazı merkezlerde term doğumlarda geç kord klemplenmesi uygulanmamaktadır. Yine bazı merkezlerde anne ve yenidoğan arasında cilt cilde temas engellenirken Amerika Pediatri Akademisi'nin temasın engellenmesine dair bir önerisi yoktur. COVID-19 enfeksiyonu olan anneler doğum odasında cerrahi maske takarak ve uygun el hijyeni ile cilt cilde temasta bulunabilir ve emzirme yapabilirler 35,38 .

\section{POSTPARTUM BAKIM}

Enfeksiyon kontrol önlemleri - Genel olarak, şüpheli veya doğrulanmış SARS-CoV-2 enfeksiyonu olan hastalar, enfekte olmayan hastalardan izole edilmeli ve standart enfeksiyon kontrol kılavuzlarına göre hareket edilmelidir.

\section{Maternal izlem}

- COVID-19 tanilı asemptomatik hastalarda rutin postpartum maternal izlem yeterlidir.
- Hafif hastalığı olanlarda vital bulgular ve alınan sıvı- idrar çıkışı takibi vajinal doğum sonrasinda 24 saat, sezaryen sonrası 48 saat boyunca 4 saatte bir yapılmalıdır.

- Orta düzeyde hastalığı olanlarda ilk 24 saatte sürekli pulse oksimetre takibi yapılmalıdır.

- Ciddi ve kritik hastalarda yoğun bakım ünitesinde çok yakın maternal izlem yapılmalıdır.

\section{Venöz tromboembolizm profilaksisi}

Ciddi/kritik COVID-19'lu hastalarda doğum sonrası herhangi bir kontrendikasyon yoksa profilaktik doz antikoagülasyon önerilir ve genellikle hasta taburcu edildiğinde kesilir. Asemptomatik veya hafif semptomatik olan ve COVID-19 dışındaki nedenlerle (örneğin doğum) hastaneye yatırılan COVID-19'lu gebeler, önceki venöz tromboembolizm (VTE) gibi başka trombotik risk faktörleri yoksa doğum sonrası antikoagülasyon gerektirmez. Emzirme döneminde düşük moleküler ağırlıklı heparin veya anfraksiyone heparin kullanılabilir.

\section{Postpartum Analjezi}

Asetaminofen tercih edilen analjezik ajandır; bununla birlikte, klinik olarak endike olduğunda nonsteroid antiinflamatuar ilaçlar (NSAID'ler) kullanılabilir.

\section{Postpartum Ateş}

COVID-19'lu hastalarda postpartum ateşin ayırıcı tanısında enfeksiyonun yanı sıra doğum sonrası endometrit, cerrahi alan enfeksiyonu, mastit, grip, piyelonefrit, diğer viral veya bakteriyel solunum yolu enfeksiyonları da düşünülmelidir.

\section{SARS-CoV-2 aşıları}

Tüm yetişkinlerde olduğu gibi doğum sonrası kadınlara da COVID-19 aşısı önerilmektedir. Daha da önemlisi, maternal aşının neden olduğu maternal COVID-19 antikorları anne sütüne geçebilir ve bebeğe pasif koruma sağlayabilir. 


\section{Yenidoğan değerlendirmesi}

Kesin veya olası COVID-19 hastası annelerden doğan bebeklere ilk 24 saat sonrasında SARSCoV-2 PCR testi yapılmalıdır ${ }^{39}$. Ilk test negatifse doğum sonrası 48. saatte ikinci test yapılmalıdır. Sağlıklı, asemptomatik bir yenidoğan 48 saatten önce taburcu edilecekse, 24 ila 48 saat arasında tek bir test yapılabilir. Test fetal nazofarinks, orofarinks ve nazal bölgeden sürüntü şeklinde alınmalıdır. Yenidoğanlarda serolojik testlerin yapılması önerilmemektedir.

\section{Hastanede anne-bebek teması}

Yenidoğana annesinden SARS-CoV-2 bulaşma riski düşüktür. Veriler, yenidoğanın ayrı bir odada mı yoksa annesinin yanında mı kalması konusunda SARS-CoV-2 enfeksiyonu riskinde fark olmadığını göstermektedir ${ }^{36,39}$. Bununla birlikte, anneler bebekleriyle temas sirasinda maske takmalı ve el hijyenine dikkat etmelidirler.

\section{Emzirme}

Anne sütü alımından SARS-CoV-2 bulaşma riski belirsizdir, ancak çok düşük görünmektedir (40). Anneye ve bebeğe sağladığı birçok fayda nedeniyle emzirmenin teşvik edilmesi gerektiği konusunda genel bir fikir birliği vardır. Maternal COVID-19 enfeksiyonu veya maternal COVID-19 aşısı durumunda, bebek virüse karşı pasif antikor koruması alabilir. Çünkü anne sütü maternal antikorlar ve diğer anti-enfektif faktörler için bir kaynaktır.

Çıkar Çatışması Beyanı: Yazarlar çıkar çatışması olmadığını bildirmişlerdir.

Finansal Destek: Bu çalışma her hangi bir fon tarafından desteklenmemiştir.

Declaration of ConflictingInterests: The authors declare that they have no conflict of interest.

Financial Disclosure: No financial support was received.

\section{KAYNAKLAR}

1. World Health Organization. Director-General's remarks at the media briefing on 2019-nCoV on 11 February

2020.https://www.who.int/dg/speeches/detail/w ho-director-general-s-remarks-at-the-mediabriefing-on-2019-ncov-on-11-february-2020 03-2020)

2. Centers for Disease Control and Prevention. Commercial Laboratory Seroprevalence Survey Data. https://www.cdc.gov/coronavirus/2019ncov/cases-updates/commercial-lab-surveys.html (Accessed on July 06, 2020).

3. T.C. Sağlık Bakanlığı, Halk Sağlığı Genel Müdürlüğü. $\quad$ COVID-19 Rehberi. https://hsgm.saglik.gov.tr/depo/covid19/rehberle r/COVID-19_Rehberi.pdf (02-04-2020)

4. Honein MA, Christie A, Rose DA, et al. Summary of Guidance for Public Health Strategies to Address High Levels of Community Transmission of SARSCoV-2 and Related Deaths, December 2020. MMWR Morb Mortal Wkly Rep 2020; 69: 1860.

5 . information/physician-faqs/covid-19-faqs-for-obgyns-obstetrics (Accessed on July 13, 2021).

6. Male V. Are COVID-19 vaccines safe in pregnancy? Nat Rev Immunol 2021; 21: 200.

7. FDA. Emergency Use Authorization (EUA) . PfizerBioNTech COVID-19 Vacci ne/BNT162b2 https://www.fda.gov/emergency-preparednessand-response/coronavirus-disease-2019-covid19/pfizer-biontech-covid-19-vaccine (Acc essed on February 25, 2021).

8. Emergency Use Authorization (EUA). Moderna COVID-19 Vaccine/mRNA-12 73 https://www.fda.gov/emergency-preparednessand-response/coronaviru s-disease-2019-covid19/moderna-covid-19-vaccine (Accessed on February 25, 2021).

9. CDC National Center for Immunization \& Respiratory Diseases. COVID 19 vaccine safety update. Advisory Committee on Immunization Practices (ACIP) March 1, 2021 https://www.cdc.gov/vaccines/acip/meetings/do 
wnloads/sli des-2021-02/28-03-01/05-covidShimabukuro.pdf (Accessed on March 02, 2021).

10. American College of Obstetricians and Gynecologists. Practice advisory: Vaccinating pregnant and lactating patients against COVID19https://www.acog.org/en/clinical/clinicalguidance/practice advisory/articles/2020/12/vaccinating-Pregnantand-Lactating-Patients-Against-COVID-19

(Accessed on February 08, 2021).

11. Zambrano LD, Ellington S, Strid P, et al. Update: Characteristics of Symptomatic Women of Reproductive Age with Laboratory-Confirmed SARS-CoV-2 Infection by Pregnancy Status- United States, January 22- Octaber 3, 2020. MMWR Morb Mortal Wkly Rep 2020; 69: 1641.

12. Yanes-Lane M, Winters N, Fregonese F, et al. Proportion of asymptomatic infection among COVID-19 positive persons and their transmission potential: A systematic review and meta-analysis. PLoS One 2020; 15:e0241536.

13. Allotey J, Stallings E, Bonet M, et al. Clinical manifestations, risk factors, and maternal and perinatal outcomes of coronavirus disease 2019 in pregnancy: living systematic review and metaanalysis. BMJ 2020; 370:m3320.

14. Oshay RR, Chen MYC, Fields BKK, et al. COVID-19 in pregnancy: a systematic review of chest CT findings and associated clinical features in 427 patients. Clin Imaging 2021; 75:75.

15. NIH COVID-19 Treatment Guidelines https://covid19treatmentguidelines.nih.gov/overvi ew/management-of-covid-19/ (Accessed on April 22, 2020).

16. WHO scientific brief. Definition and categorization of the timing of mother-to-child transmission of SARS-CoV-2. February 8, 2021 https://www.who.int/publications/i/item/WHO2019-nCoV-mother-to-child-transmission2021.1(Accessed on February 11, 2021).

17. Kirtsman M, Diambomba Y, Poutanen SM, et al. Probable congenital SARS $\mathrm{CoV}-2$ infection in a neonate born to a woman with active SARS-CoV-2 infection. CMAJ 2020; 192: E647.
18. Shah PS, Diambomba Y, Acharya G, et al. Classification system and case definition for SARSCoV-2 infection in pregnant women, fetuses, and neonates. Acta Obstet Gynecol Scand 2020; 99: 565.

19. Woodworth KR, Olsen EO, Neelam V, et al. Birth and Infant Outcomes Following LaboratoryConfirmed SARS-CoV-2 Infection in Pregnancy SET-NET, 16 Jurisdictions, March 29-October 14, 2020. MMWR Morb Mortal Wkly Rep 2020; 69: 1635.

20. Conde-Agudelo A, Romero R. SARS-COV-2 infection during pregnancy and risk of preeclampsia: a systematic review and metaanalysis. Am J Obstet Gynecol 2021.

21. Mullins E, Hudak ML, Banerjee J, et al. Pregnancy and neonatal outcomes of COVID-19: coreporting of common outcomes from PAN-COVID and AAPSONPM registries. Ultrasound Obstet Gynecol 2021; 57: 573.

22. Norman M, Navér L, Söderling J, et al. Association of Maternal SARS-CoV-2 Infection in Pregnancy With Neonatal Outcomes. JAMA 2021; 325:2076.

23. Donders F, Lonnée-Hoffmann R, Tsiakalos A, et al. ISIDOG Recommendations Concerning COVID-19 and Pregnancy. Diagnostics (Basel) 2020; 10.

24. Moro F, Buonsenso D, Moruzzi MC, et al. How to perform lung ultrasound in pregnant women with suspected COVID-19. Ultrasound Obstet Gynecol 2020; 55: 593.

25. Gebelikte Coronavirüs Enfeksiyonu (COVID-19) Hakkında Görüş , www.tmftp.org (3. Bilgilendirme, 03.04.2020).

26. T.C. Sağlık Bakanlığı Halk Sağlığı Genel Müdürlügü. https://covid19.saglik.gov.tr/TR75284/covid-19-solunum-sistemi-hastaliklarininyaygin-oldugu-donemde-saglik-kuruluslarindagebe-takibi.html (16 Ekim 2020, Ankara)

27. Society for Maternal-Fetal Medicine. Management Considerations for Pregn ant Patients With COVID-19

https://s3.amazonaws.com/cdn.smfm.org/media/ 2401/SMFM_COVID_Management_of_COVID_pos_pr eg_patients_6-16-20._PDF.pdf (Accessed on October 27, 2020). 
28. World Health Organization (WHO). Clinical management of severe acute res piratory infection (SARI) when COVID-19 disease is suspected" interim guid ance 27 May 2020.

29. Wong AY, MacKenna B, Morton CE, et al. Use of non-steroidal anti-inflammatory drugs and risk of death from COVID-19: an OpenSAFELY cohort analysis based on two cohorts. Ann Rheum Dis 2021; 80: 943.

30. T.C. Sağlık Bakanlığı Halk Sağlığı Genel Müdürlüğü. $\quad$ https://covid19.saglik.gov.tr/TR66301/covid-19-rehberi.html (7 Mayıs 2021).

31. Burwick RM, Yawetz S, Stephenson KE, et al. Compassionate Use of Remdesivir in Pregnant Women with Severe Covid-19. Clin Infect Dis 2020.

32. Chen D, Yang H, Cao Y, et al. Expert consensus for managing pregnant women and neonates born to mothers with suspected or confirmed novel coronavirus (COVID-19) infection. Int J Gynaecol Obstet 2020; 149: 130.

33. Stephens AJ, Barton JR, Bentum NA, Blackwell SC, Sibai BM. General Guidelines in the Management of an Obstetrical Patient on the Labor and Delivery Unit during the COVID-19 Pandemic. Am J Perinatol 2020; 37: 829-36.

34. Tolcher MC, McKinney JR, Eppes CS, et al. Prone Positioning for Pregnant Women With Hypoxemia
Due to Coronavirus Disease 2019 (COVID-19). Obstet Gynecol 2020; 136: 259.

35. https://www.acog.org/clinicalinformation/physician-faqs/covid-19-faqs-for-obgyns-obstetrics (Accessed on October 29, 2020).

36. Walker KF, O'Donoghue $\mathrm{K}$, Grace $\mathrm{N}$, et al. Maternal transmission of SARS COV-2 to the neonate, and possible routes for such transmission: a systematic review and critical analysis. BJOG 2020; 127: 1324.

37. Schwartz DA. An Analysis of 38 Pregnant Women With COVID-19, Their Newborn Infants, and Maternal-Fetal Transmission of SARS-CoV-2: Maternal Coronavirus Infections and Pregnancy Outcomes. Arch Pathol Lab Med 2020; 144: 799.

38. Salvatore CM, Han JY, Acker KP, et al. Neonatal management and outcomes during the COVID-19 pandemic: an observation cohort study. Lancet Child Adolesc Health 2020; 4: 721.

39.

CDC.

Newborns.

https://www.cdc.gov/coronavirus/2019-

ncov/hcp/caring-for-newborns.html.

40. WHO. Breastfeeding and COVID-19. Scientific Brief. $23 \quad$ June 2020 https://www.who.int/publications/i/item/106653 32639 (Accessed on June 25, 2020). 